\title{
Melatonin-enhanced hyperactivation of hamster sperm
}

\author{
Masakatsu Fujinoki \\ Department of Physiology, School of Medicine, Dokkyo Medical University, Mibu, Tochigi 321-0293, Japan \\ Correspondence should be addressed to M Fujinoki; Email: fujinoki@dokkyomed.ac.jp
}

\begin{abstract}
The effects of melatonin on reproductive function were examined using hamster spermatozoa. When $1 \mathrm{pM}$ to $1 \mu \mathrm{M}$ melatonin was added to the mTALP medium, hyperactivation was significantly enhanced. Antagonists and agonists of the melatonin receptor (i.e., MT1 and MT2) were added to the medium. Luzindole, an MT1 and MT2 competitive antagonist, significantly inhibited melatonin-induced hyperactivation, whereas the MT2-specific antagonists, 4-phenyl-2-propionamidotetralin and N-pentanoyl-2-benzyltryptamine, had no effect. Moreover, hyperactivation was significantly enhanced when non-specific agonists, such as 6-chloromelatonin and 2-iodomelatonin, were added to the medium. 8-Methoxy-2-propionamidotetralin, which is a strong MT2 agonist and a weak MT1 agonist, significantly increased hyperactivation, although the effect was weak. Therefore, it is likely that melatonin enhances sperm hyperactivation via the MT1 receptor.

Reproduction (2008) 136 533-541
\end{abstract}

\section{Introduction}

$\mathrm{N}$-acetyl-5-methoxytryptamine (melatonin) is produced and secreted by the pineal gland and retina in a circadian rhythm, and it also regulates reproduction in seasonal breeders (Bronson \& Heideman 1994, Turek \& Van Cauter 1994). In the hamster, reproduction is inhibited by a long exposure to melatonin and stimulated by a short exposure, whereas in sheep, it is stimulated by a long exposure and inhibited by a short exposure. Moreover, acrosin activity is increased in spermatozoa obtained from rams with melatonin implants (Kokolis et al. 2000).

Melatonin exerts its effects via specific receptors. Two have been cloned, termed melatonin receptor type 1 (MT1) and type 2 (MT2), and they have seven transmembrane G-protein-coupled receptors (Reppert et al. 1994, 1995). The MT1 receptor is localized in the suprachiasmatic nucleus (SCN; Weaver \& Reppert 1996), and the MT2 receptor exists in the retina and brain (Reppert et al. 1995). Both receptors bind melatonin with high affinity and are associated with the inhibition of cyclic AMP (cAMP) production (Reppert et al. 1994, 1995, Browning et al. 2000). The MT1 receptor has also been detected in the Leydig cells of the testis and linked to the inhibition of androgen production (Frungieri et al. 2005). In the rat SCN, melatonin inhibits the increase in CAMP induced by vasoactive intestinal peptide (Vanecek \& Watanabe 1998) and is involved in the regulation of nitric oxide synthase (NOS) activity (Starkey 1996). In the hamster retina, melatonin decreases NOS activity and L-arginine influx, and inhibits the accumulation of cGMP induced by both L-arginine and sodium nitroprusside (Sáenz et al. 2002).

In order to fertilize the egg, mammalian spermatozoa have to be capacitated and then undergo the acrosome reaction and hyperactivation. The acrosome reaction is a modified exocytotic event involving the acrosome, a large secretory granule-like organelle in the sperm head, and the overlying sperm plasma membrane (Yudin et al. 1988). It is necessary for the penetration of the zona pellucida, the glycoprotein envelope of the ovum, and for sperm-egg plasma membrane fusion (Yanagimachi 1994). Hyperactivation is a specialized movement of the sperm flagellum that creates the propulsive force for the penetration of the zona pellucida. Hyperactivated spermatozoa exhibit large bend amplitude, whiplash, and frenzied flagellar movements (Morisawa 1994, Yanagimachi 1994, Suarez \& Ho 2003). Albumin, $\mathrm{Ca}^{2+}$, and $\mathrm{HCO}_{3}^{-}$ are essential in the process of capacitation of mammalian spermatozoa. Albumin promotes capacitation by removing cholesterol from the sperm plasma membrane (Langlais \& Roberts 1985), $\mathrm{Ca}^{2+}$ is involved in the intracellular signaling (Visconti \& Kopf 1998, Visconti et al. 1998, Ho \& Suarez 2001, Ho et al. 2002), and $\mathrm{HCO}_{3}^{-}$ stimulates adenylate cyclase to increase cAMP (Okamura et al. 1985). Stimulation of these essential components leads to many sperm proteins being phosphorylated during capacitation (Fujinoki et al. 2006).

Bornman et al. (1989) reported that human seminal plasma contains melatonin, but that it did not affect sperm motility, whereas Van Vuuren et al. (1988) suggested that melatonin may have an effect, because 
they found melatonin receptors in human spermatozoa (Van Vuuren et al. 1992). A high concentration of melatonin inhibited the quality of sperm motility in rats, according to Gwayi \& Bernard (2002), but the regulation of sperm function by melatonin is not yet understood.

Therefore, in the present study, the effects of melatonin on sperm hyperactivation in the hamster, which is a seasonally breeding mammal, were investigated.

\section{Results}

\section{Effects of melatonin on sperm hyperactivation}

When $1 \mathrm{nM}$ melatonin was added to the mTALP medium, it significantly increased sperm hyperactivation after incubation for $0.5,1$, and $2 \mathrm{~h}$, although it did not affect the $\%$ motility of spermatozoa (Fig. 1). At incubation for $0 \mathrm{~h}$, there were no hyperactivated spermatozoa. After incubation for 3 and $4 \mathrm{~h}$, there were no significant differences between $1 \mathrm{nM}$ melatonin and vehicle.

Next, the dose-dependent effect of melatonin on hyperactivation was examined (Fig. 2). At incubation for $0 \mathrm{~h}$, there were no hyperactivated spermatozoa (Fig. 2A). After incubation for only $0.5 \mathrm{~h}, 1 \mathrm{nM}$
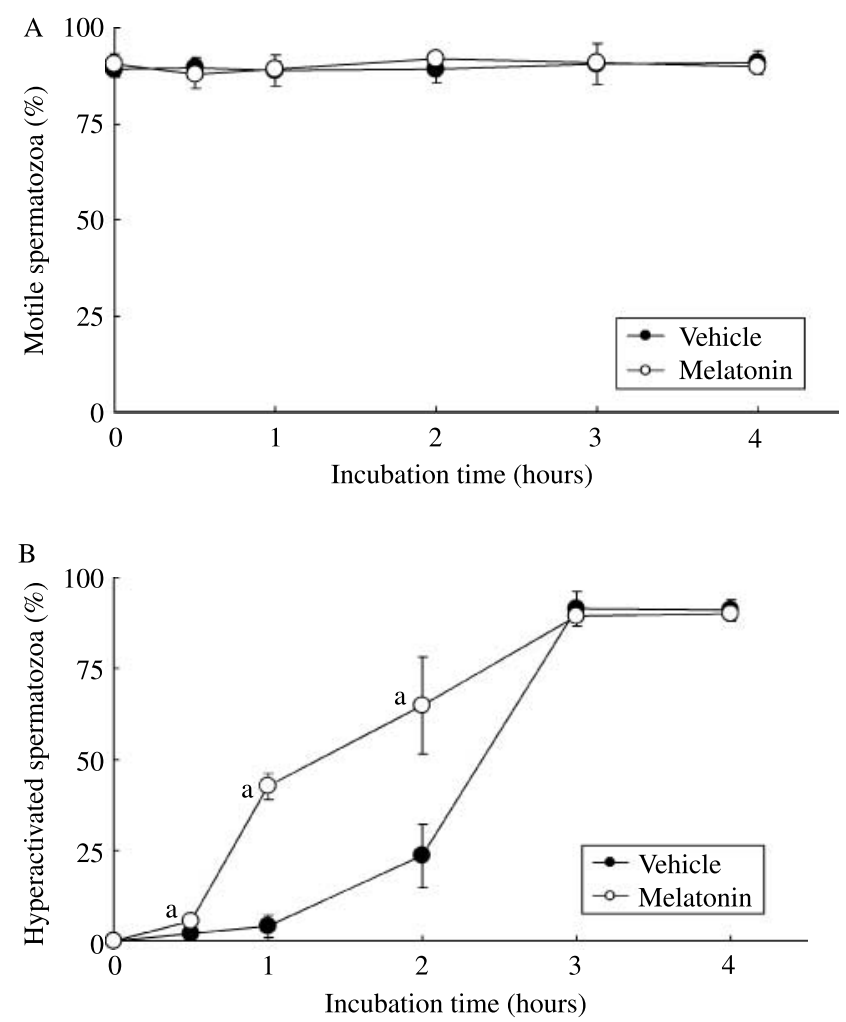

Figure 1 Enhancement of hyperactivation by melatonin. Percentages of (A) motile spermatozoa and (B) hyperactivated spermatozoa are shown, when $1 \mathrm{nM}$ melatonin added to the mTALP medium. Data represent mean \pm s.D. Vehicle $(\bullet)$ and melatonin $(O)$ indicate mTALP $+0.1 \%$ ethanol and $\mathrm{mTALP}+1 \mathrm{nM}$ melatonin $+0.1 \%$ ethanol respectively. ${ }^{a}$ Significant difference compared with vehicle $(P<0.05)$. melatonin significantly increased sperm hyperactivation compared with vehicle or $1 \mathrm{fM}, 10 \mathrm{fM}$, and $10 \mu \mathrm{M}$ of melatonin (Fig. 2B). There were no significant differences between $1 \mathrm{nM}$ melatonin and $100 \mathrm{fM}$ to $1 \mu \mathrm{M}$ melatonin. After incubation for $1 \mathrm{~h}$ (Fig. 2C) or $2 \mathrm{~h}$ (Fig. 2D), $1 \mathrm{pM}$ to $1 \mu \mathrm{M}$ melatonin significantly increased sperm hyperactivation compared with vehicle or 1-100 fM and $10 \mu \mathrm{M}$ melatonin. Moreover, after incubation for $1 \mathrm{~h}$ (Fig. 2C), $10 \mu \mathrm{M}$ melatonin significantly increased hyperactivation compared with vehicle (Fig. 2C). After incubation for 3 and $4 \mathrm{~h}$, there were no significant differences among the various concentrations (Fig. 2A).

\section{Effects of melatonin receptor antagonists on sperm hyperactivation}

Luzindole, 4-phenyl-2-propionamidotetralin (4P-PDOT), and $\mathrm{N}$-pentanoyl-2-benzyltryptamine (DH97), which are melatonin receptor antagonists, were used to investigate the involvement of the melatonin receptors in the regulation of sperm hyperactivation. After incubation for 1 or $2 \mathrm{~h}, 1 \mathrm{nM}$ and $1 \mu \mathrm{M}$ luzindole, which is an MT1 and MT2 competitive antagonist, significantly inhibited the sperm hyperactivation induced by $1 \mathrm{nM}$ melatonin, which was an average value of the effective concentrations (Fig. 3A). However, $1 \mathrm{nM}$ melatonin significantly increased sperm hyperactivation after incubation for 1 or $2 \mathrm{~h}$, even if luzindole was added to the medium. 4P-PDOT and DH97, which are MT2-specific antagonists, did not inhibit the \% hyperactivated motility of spermatozoa when $1 \mathrm{nM}$ melatonin was added to the medium (Fig. 3B and C). Neither of the melatonin receptor antagonists affected the $\%$ motility of spermatozoa (data not shown).

\section{Effects of melatonin receptor agonists on sperm hyperactivation}

8-Methoxy-2-propionamidotetralin (8M-PDOT), which is a strong MT2 agonist and a weak MT1 agonist, significantly increased sperm hyperactivation after incubation for 1 or $2 \mathrm{~h}$ (Fig. 4A), although it did not affect the $\%$ motility of spermatozoa (data not shown). It was observed that $1 \mathrm{pM}$ significantly increased sperm hyperactivation after incubation for $1 \mathrm{~h}$ compared with vehicle or $10 \mathrm{fM}, 10 \mathrm{pM}, 100 \mathrm{pM}, 1 \mu \mathrm{M}$, and $10 \mu \mathrm{M} 8 \mathrm{M}$ PDOT (Fig. 4B). After incubation for $2 \mathrm{~h}$ (Fig. 4C), $100 \mathrm{fM}$ to $10 \mathrm{pM} 8 \mathrm{M}$-PDOT significantly increased sperm hyperactivation compared with vehicle and the other concentrations. Moreover, $10 \mathrm{fM}$ 8M-PDOT also significantly increased sperm hyperactivation after incubation for $2 \mathrm{~h}$ compared with vehicle only (Fig. 4C).

The two non-specific melatonin agonists, 6-chloromelatonin and 2-iodomelatonin, also significantly increased sperm hyperactivation (Figs 5A and $6 \mathrm{~A})$, but did not affect the \% motility of spermatozoa (data not shown). As shown in Fig. 5B, after incubation for $0.5 \mathrm{~h}, 1-100 \mathrm{fM}$ 6-chloromelatonin significantly 
increased sperm hyperactivation compared with vehicle or $10 \mathrm{pM}$ to $10 \mu \mathrm{M}$, and $1 \mathrm{fM}$ significantly increased sperm hyperactivation compared with $1 \mathrm{pM}$. Moreover, $1 \mathrm{pM}$ 6-chloromelatonin significantly increased sperm hyperactivation compared with $1 \mathrm{nM}, 100 \mathrm{nM}$, and $10 \mu \mathrm{M}$. After incubation for $1 \mathrm{~h}$ (Fig. 5C), $1 \mathrm{fM}$ to $10 \mathrm{pM}$ of 6 -chloromelatonin significantly increased sperm hyperactivation compared with vehicle and the other concentrations. After incubation for $2 \mathrm{~h}$ (Fig. 5D),
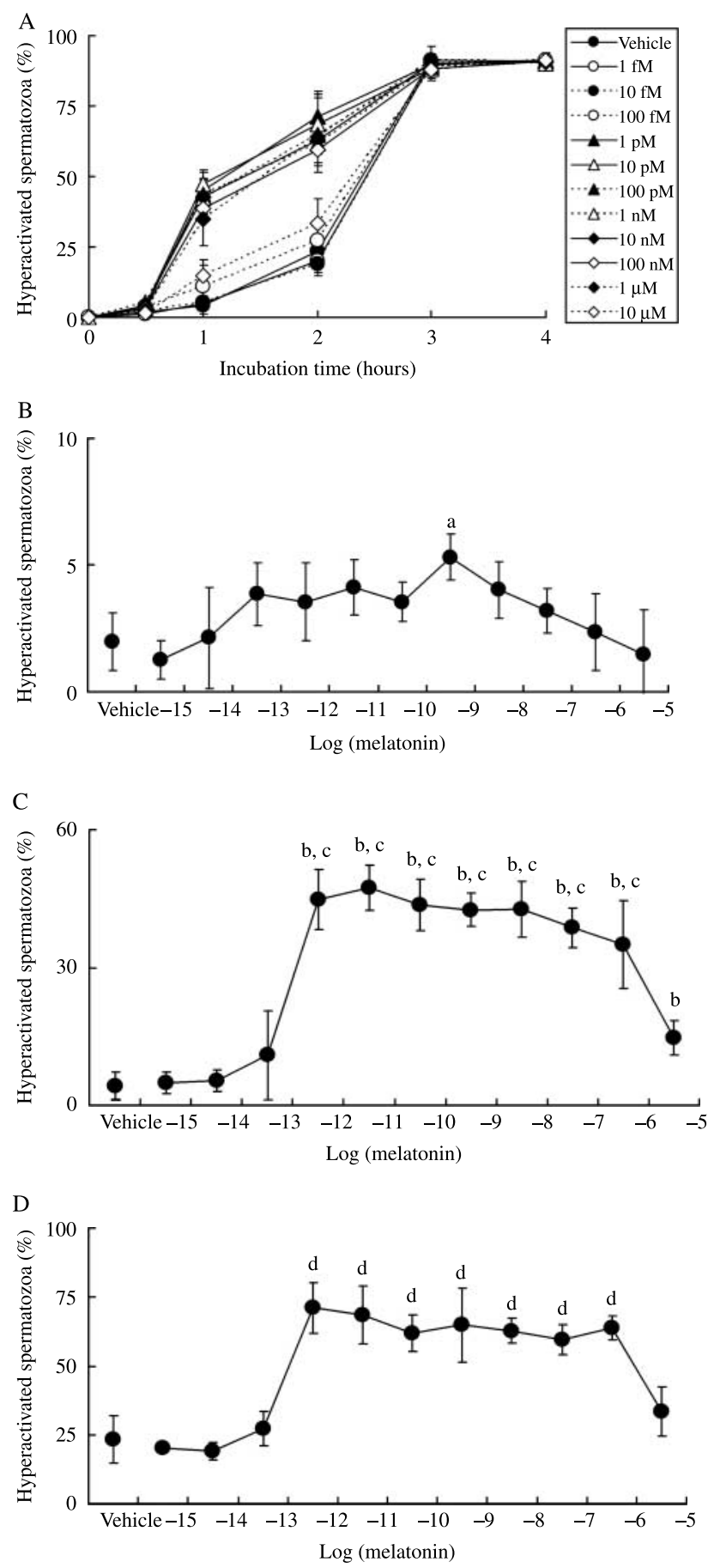

$1 \mathrm{fM}$ to $10 \mathrm{nM}$ significantly increased sperm hyperactivation compared with vehicle and the other concentrations. After incubation for $3 \mathrm{~h}$ (Fig. 5E), $100 \mathrm{nM}$ to $10 \mu \mathrm{M}$ 6-chloromelatonin significantly suppressed sperm hyperactivation compared with vehicle and the other concentrations.

As shown in Fig. 6B, 1-100 fM 2-iodomelatonin significantly increased hyperactivation after incubation for $0.5 \mathrm{~h}$ compared with vehicle or $1 \mu \mathrm{M}$ and $10 \mu \mathrm{M}$. After incubation for $1 \mathrm{~h}$ (Fig. 6C), $1 \mathrm{fM}$ to $10 \mathrm{pM}$ 2 -iodomelatonin significantly increased sperm hyperactivation compared with vehicle or $1 \mathrm{nM}$ to $10 \mu \mathrm{M}$, $100 \mathrm{pM}$ significantly increased sperm hyperactivation compared with vehicle or $10 \mathrm{nM}$ to $10 \mu \mathrm{M}$, and $1 \mathrm{nM}$ significantly increased sperm hyperactivation compared with vehicle. Moreover, 100 fM 2-iodomelatonin significantly increased sperm hyperactivation compared with $100 \mathrm{pM}$. After incubation for $2 \mathrm{~h}$ (Fig. 6D), $1 \mathrm{fM}$ to $100 \mathrm{nM} 2$-iodomelatonin significantly increased sperm hyperactivation compared with vehicle or $1 \mu \mathrm{M}$ and $10 \mu \mathrm{M} 2$ 2-iodomelatonin, neither of which affected sperm hyperactivation at all.

\section{Effects of $\mathrm{Ca}^{2+}$ and albumin on sperm hyperactivation}

As shown in Fig. 7A, \% motility of spermatozoa was significantly decreased after incubation for $2 \mathrm{~h}$ in the mTALP medium without $\mathrm{Ca}^{2+}$, and after incubation for 3 or $4 \mathrm{~h}$, most spermatozoa were not motile. Melatonin did not affect \% motility of spermatozoa in the mTALP medium without $\mathrm{Ca}^{2+}$. As for hyperactivation, hamster spermatozoa could not be hyperactivated at all in the mTALP medium without $\mathrm{Ca}^{2+}$, even if melatonin was added (Fig. 7B).

Hamster spermatozoa could not be hyperactivated at all in the mTALP medium without BSA, even if melatonin was added (Fig. 8), although the addition of BSA did not affect $\%$ motility of spermatozoa (data not shown).

\footnotetext{
Figure 2 Dose-dependent effects of melatonin on hyperactivation. Percentage of hyperactivated spermatozoa is shown (A) as an overview of effects and after incubation for (B) 0.5 , (C) 1, and (D) $2 \mathrm{~h}$ after melatonin was added to the mTALP medium. Data represent mean \pm S.D. (vehicle), $\mathrm{mTALP}+0.1 \%$ ethanol; $(1 \mathrm{fM}$ or -15$), \mathrm{mTALP}+1 \mathrm{fM}$ melatonin $+0.1 \%$ ethanol; $(10 \mathrm{fM}$ or -14$)$, mTALP $+10 \mathrm{fM}$ melatonin $+0.1 \%$ ethanol; $(100 \mathrm{fM}$ or -13$), \mathrm{mTALP}+100 \mathrm{fM}$ melatonin + $0.1 \%$ ethanol; $(1 \mathrm{pM}$ or -12$), \mathrm{mTALP}+1 \mathrm{pM}$ melatonin $+0.1 \%$ ethanol; $(10 \mathrm{pM}$ or -11$), \mathrm{mTALP}+10 \mathrm{pM}$ melatonin $+0.1 \%$ ethanol; $(100 \mathrm{pM}$ or -10$), \mathrm{mTALP}+100 \mathrm{pM}$ melatonin $+0.1 \%$ ethanol; $(1 \mathrm{nM}$ or -9$), \operatorname{mTALP}+1 \mathrm{nM}$ melatonin $+0.1 \%$ ethanol; $(10 \mathrm{nM}$ or -8$)$, mTALP + $10 \mathrm{nM}$ melatonin $+0.1 \%$ ethanol; $(100 \mathrm{nM}$ or -7$), \mathrm{mTALP}+$ $100 \mathrm{nM}$ melatonin $+0.1 \%$ ethanol; $(1 \mu \mathrm{M}$ or -6$), \mathrm{mTALP}+1 \mu \mathrm{M}$ melatonin $+0.1 \%$ ethanol; and $(10 \mu \mathrm{M}$ or -5$)$, mTALP $+10 \mu \mathrm{M}$

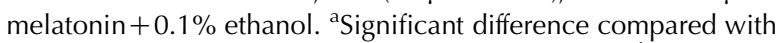
vehicle, or $1 \mathrm{fM}, 10 \mathrm{fM}$, and $1 \mathrm{nM}-10 \mu \mathrm{M}(P<0.05)$; ${ }^{b}$ significant difference compared with vehicle $(P<0.05)$; ${ }^{c}$ significant difference compared with $1-100 \mathrm{fM}$ and $10 \mu \mathrm{M}(P<0.05)$; ${ }^{\mathrm{d}}$ significant difference compared with vehicle or $1-100 \mathrm{fM}$ and $10 \mu \mathrm{M}(P<0.05)$.
} 


\section{Discussion}

Melatonin is mainly produced and secreted by the pineal gland and retina (Turek \& Van Cauter 1994), but Kvetnoy (1999) suggested that it was also produced in other tissues such as the Harderian gland, gut mucosa, cerebellum, airway epithelium, liver, kidney, adrenals, thymus,
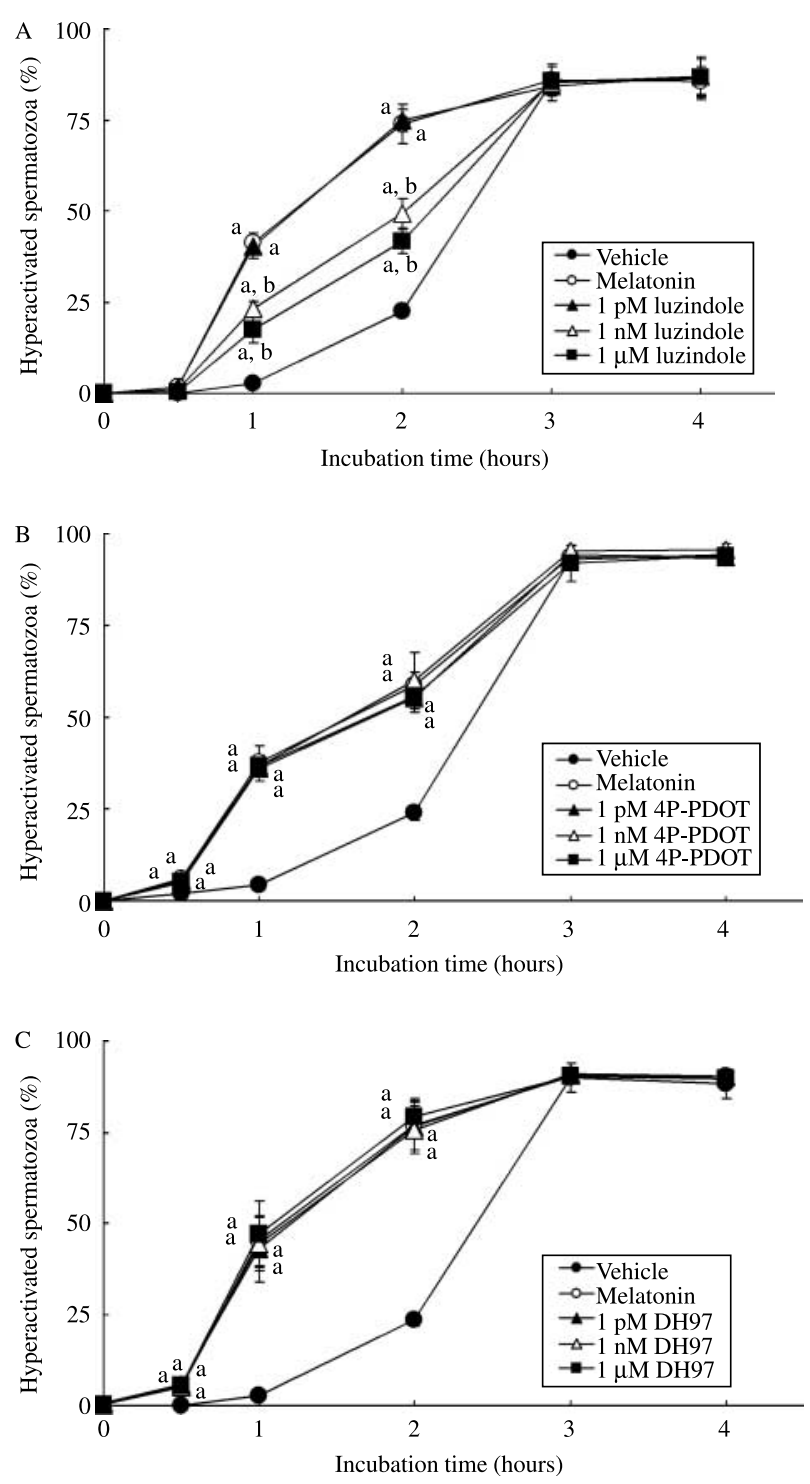

Figure 3 Effects of melatonin receptor antagonists on melatoninenhanced hyperactivation. (A) Luzindole, which is an MT1 and MT2 competitive receptor antagonist, (B) 4P-PDOT, and (C) DH97, which are MT2-specific receptor antagonists, were respectively added to the mTALP medium before $1 \mathrm{nM}$ melatonin was added to the mTALP medium. Data represent mean \pm s.D. Vehicle $(\mathbf{O})$, melatonin $(O), 1 \mathrm{pM}$ antagonist $(\boldsymbol{\Lambda}), 1 \mathrm{nM}$ antagonist $(\Delta)$, and $1 \mu \mathrm{M}$ antagonist $(\boldsymbol{\square})$ indicate mTALP $+0.1 \%$ ethanol, mTALP $+1 \mathrm{nM}$ melatonin $+0.1 \%$ ethanol, $\mathrm{mTALP}+1 \mathrm{nM}$ melatonin $+1 \mathrm{pM}$ antagonist $+0.1 \%$ ethanol, $\mathrm{mTALP}+$ $1 \mathrm{nM}$ melatonin $+1 \mathrm{nM}$ antagonist $+0.1 \%$ ethanol, and $\mathrm{mTALP}+1 \mathrm{nM}$ melatonin $+1 \mu \mathrm{M}$ antagonist $+0.1 \%$ ethanol. ${ }^{\mathrm{a}}$ Significant difference compared with vehicle $(P<0.05)$; ${ }^{b}$ significant difference compared with melatonin and $1 \mathrm{pM}$ antagonist $(P<0.05)$.
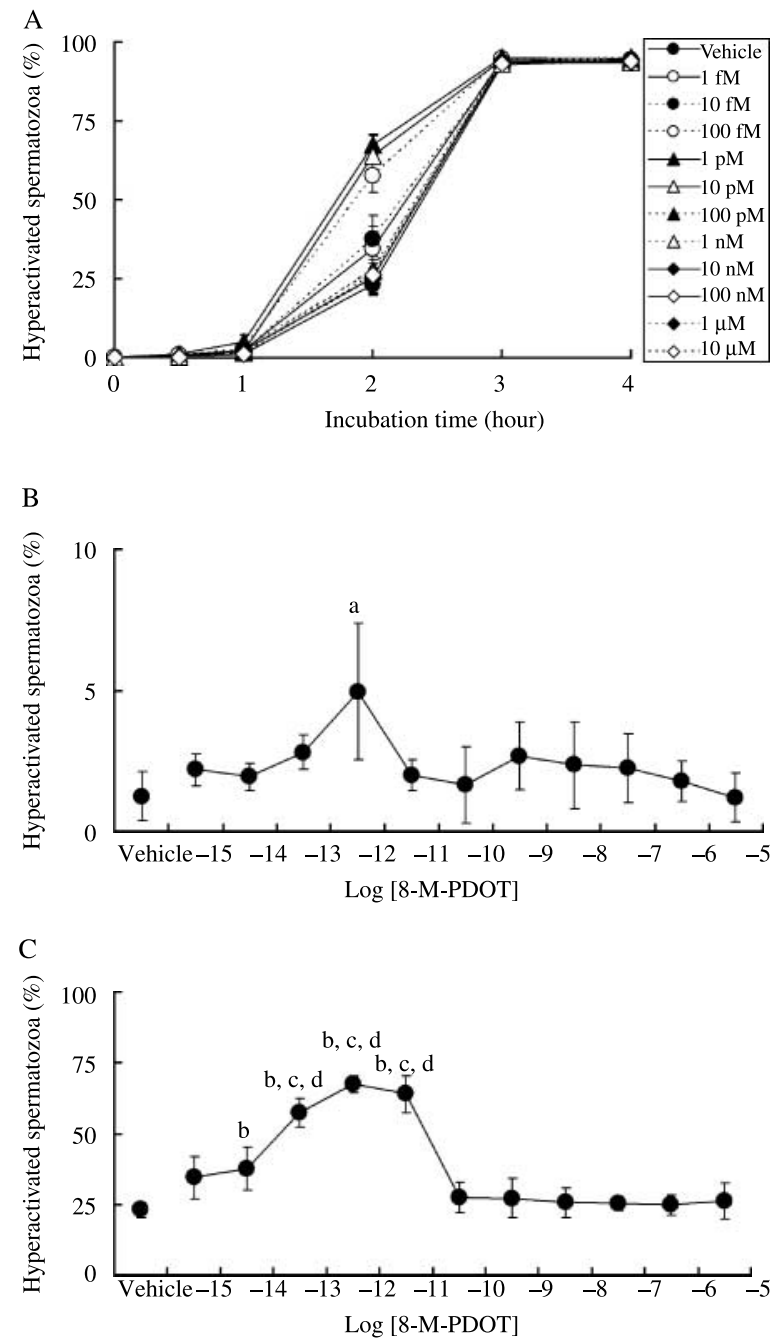

Figure 4 Effects of $8 \mathrm{M}$-PDOT, which is a strong MT2 receptor agonist and a weak MT1 receptor agonist, on melatonin-enhanced hyperactivation. Percentage of hyperactivated spermatozoa is shown (A) as an overview of effects and after incubation for (B) 1 and (C) $2 \mathrm{~h}$ after $8 \mathrm{M}$-PDOT was added to the mTALP medium. Data represent mean \pm S.D. (vehicle), $\mathrm{mTALP}+0.1 \%$ ethanol; $(1 \mathrm{fM}$ or -15$), \mathrm{mTALP}+1 \mathrm{fM}$ $8 \mathrm{M}-\mathrm{PDOT}+0.1 \%$ ethanol; $(10 \mathrm{fM}$ or -14$)$, mTALP $+10 \mathrm{fM} 8 \mathrm{M}-$ PDOT $+0.1 \%$ ethanol; $(100 \mathrm{fM}$ or -13$), \mathrm{mTALP}+100 \mathrm{fM} 8 \mathrm{M}-$ PDOT $+0.1 \%$ ethanol; $(1 \mathrm{pM}$ or -12$)$, mTALP $+1 \mathrm{pM} 8 \mathrm{M}-\mathrm{PDOT}+$ $0.1 \%$ ethanol; ( $10 \mathrm{pM}$ or -11$)$, mTALP $+10 \mathrm{pM} 8 \mathrm{M}-\mathrm{PDOT}+0.1 \%$ ethanol; (100 pM or -10$)$, mTALP + $100 \mathrm{pM} \mathrm{8M-PDOT}+0.1 \%$ ethanol; ( $1 \mathrm{nM}$ or -9$), \mathrm{mTALP}+1 \mathrm{nM} 8 \mathrm{M}-\mathrm{PDOT}+0.1 \%$ ethanol; (10 nM or -8$),$ mTALP $+10 \mathrm{nM} 8 \mathrm{M}-\mathrm{PDOT}+0.1 \%$ ethanol; $(100 \mathrm{nM}$ or $-7), \mathrm{mTALP}+100 \mathrm{nM} 8 \mathrm{M}-\mathrm{PDOT}+0.1 \%$ ethanol; $(1 \mu \mathrm{M}$ or -6$)$, $\mathrm{mTALP}+1 \mu \mathrm{M} 8 \mathrm{M}-\mathrm{PDOT}+0.1 \%$ ethanol; and $(10 \mu \mathrm{M}$ or -5$)$, mTALP $+10 \mu \mathrm{M} 8 \mathrm{M}$-PDOT $+0.1 \%$ ethanol. ${ }^{\mathrm{a}}$ Significant difference compared with vehicle or $10 \mathrm{fM}, 10 \mathrm{pM}, 100 \mathrm{pM}, 1 \mu \mathrm{M}$, and $10 \mu \mathrm{M}$ $8 \mathrm{M}-\mathrm{PDOT}(P<0.05)$; ${ }^{\mathrm{s}}$ significant difference compared with vehicle $(P<0.05)$; ${ }^{c}$ significant difference compared with $1 \mathrm{fM}$ and $10 \mathrm{fM} 8 \mathrm{M}$ PDOT $(P<0.05)$; ${ }^{d}$ significant difference compared with $100 \mathrm{pM}$ to $10 \mu \mathrm{M}$ 8M-PDOT $(P<0.05)$. 
thyroid, pancreas, ovaries, carotid body, placenta and endometrium, and non-neuroendocrine cells, such as mast cells, natural killer cells, eosinophilic leukocytes, ovarian Leydig cells, platelets, and endothelial cells.
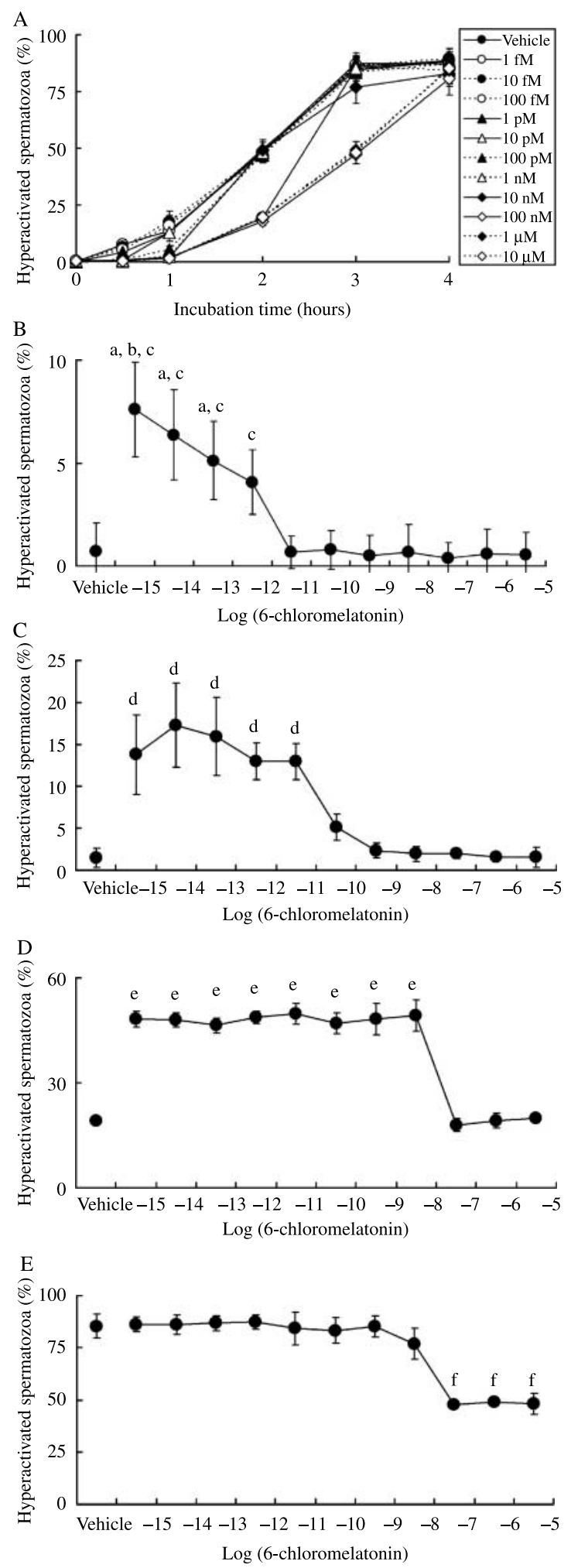

Therefore, it is likely that melatonin is a key molecule in many functions in many tissues and cells.

Capacitated mammalian spermatozoa exhibit the acrosome reaction and hyperactivation. The acrosome reaction occurs in the sperm head in a ligand-dependent manner (Yudin et al. 1988, Yanagimachi 1994) and it has been reported that progesterone, the zona pellucida, epidermal growth factor, and serotonin are ligands that induce the acrosome reaction (Meizel \& Turner 1983, Yudin et al. 1988, Osman et al. 1989, Furuya et al. 1994, Fukami et al. 2001). A recent study has indicated that progesterone enhanced hyperactivation in a concentration-dependent manner (Noguchi et al. 2008), and the results of the present study suggest that melatonin is a new ligand to be hyperactivated on hamster spermatozoa (Fig. 1). Because spermatozoa are hyperactivated in the female reproductive tract, it is probably the melatonin produced and secreted by the ovaries that acts as the ligand in the modulation of sperm hyperactivation.

In the present study, the effective concentration of melatonin for hyperactivation ranged from $1 \mathrm{pM}$ to $1 \mu \mathrm{M}$ (Fig. 2). In rat spermatozoa, $10 \mu \mathrm{M}$ melatonin significantly decreased the quality of sperm motility (Gwayi \& Bernard 2002), but in hamster spermatozoa, $10 \mu \mathrm{M}$ melatonin was not effective (Fig. 2). In a human study, the serum melatonin concentration was $10.0 \pm 1.4 \mathrm{pg} / \mathrm{ml}$ and the follicular fluid melatonin concentration was $36.5 \pm 4.8 \mathrm{pg} / \mathrm{ml}$ (Brzezinski et al. 1987), but in another study Rönnberg et al. (1990) reported that the serum melatonin concentration was $38.6 \pm 1.8 \mathrm{pM}$ and the follicular fluid melatonin concentration was $98.1 \pm 8.9 \mathrm{pM}$. Moreover, they reported that the follicular fluid melatonin concentration in the

Figure 5 Effects of 6-chloromelatonin, which is a non-specific agonist, on melatonin-enhanced hyperactivation. Percentage of hyperactivated spermatozoa is shown (A) as an overview of effects and after incubation for (B) 0.5, (C) 1, (D) 2, and (E) 3 h after 6-chloromelatonin was added to the mTALP medium. Data represent mean \pm s.D. (vehicle), mTALP $+0.1 \%$ ethanol; $(1 \mathrm{fM}$ or -15$), \operatorname{mTALP}+1 \mathrm{fM}$ 6-chloromelatonin $+0.1 \%$ ethanol; $(10 \mathrm{fM}$ or -14$)$, mTALP $+10 \mathrm{fM}$ 6-chloromelatonin $+0.1 \%$ ethanol; $(100 \mathrm{fM}$ or -13$)$, mTALP $+100 \mathrm{fM}$ 6 -chloromelatonin $+0.1 \%$ ethanol; $(1 \mathrm{pM}$ or -12$), \mathrm{mTALP}+1 \mathrm{pM}$ 6 -chloromelatonin $+0.1 \%$ ethanol; $(10 \mathrm{pM}$ or -11$), \mathrm{mTALP}+10 \mathrm{pM}$ 6-chloromelatonin $+0.1 \%$ ethanol; $(100 \mathrm{pM}$ or -10$)$, mTALP + $100 \mathrm{pM} 6$-chloromelatonin $+0.1 \%$ ethanol; $(1 \mathrm{nM}$ or -9$), \mathrm{mTALP}+$ $1 \mathrm{nM} 6$-chloromelatonin $+0.1 \%$ ethanol; $(10 \mathrm{nM}$ or -8$)$, mTALP + $10 \mathrm{nM}$ 6-chloromelatonin $+0.1 \%$ ethanol; $(100 \mathrm{nM}$ or -7$)$, mTALP+ $100 \mathrm{nM} 6$-chloromelatonin $+0.1 \%$ ethanol; $(1 \mu \mathrm{M}$ or -6$)$, mTALP+ $1 \mu \mathrm{M}$ 6-chloromelatonin $+0.1 \%$ ethanol; and $(10 \mu \mathrm{M}$ or -5$)$, mTALP $+10 \mu \mathrm{M}$ 6-chloromelatonin $+0.1 \%$ ethanol. ${ }^{\mathrm{a}}$ Significant difference compared with vehicle or $10 \mathrm{pM}, 100 \mathrm{pM}, 10 \mathrm{nM}$, and $1 \mu \mathrm{M}$ 6-chloromelatonin $(P<0.05)$; ${ }^{\mathrm{b}}$ significant difference compared with $1 \mathrm{pM} 6$-chloromelatonin $(P<0.05)$; ${ }^{c}$ significant difference compared with $1 \mathrm{nM}, 100 \mathrm{nM}$, and $10 \mu \mathrm{M}$ 6-chloromelatonin $(P<0.05)$; ${ }^{\mathrm{d}}$ significant difference compared with vehicle or $100 \mathrm{pM}$ to $10 \mu \mathrm{M}$ 6-chloromelatonin $(P<0.05)$; ${ }^{\text {significant difference compared }}$ with vehicle or $100 \mathrm{nM}$ to $10 \mu \mathrm{M} 6$-chloromelatonin $(P<0.05)$; ${ }^{\mathrm{f}}$ significant difference compared with vehicle or $1 \mathrm{fM}$ to $10 \mathrm{nM}$ 6-chloromelatonin $(P<0.05)$. 
morning was $58.9 \pm 3.8$ and $23.2 \pm 0.8 \mathrm{pM}$ during the day. Although the follicular fluid melatonin concentration in rodents is not known, it is likely to be the same as in humans because serum melatonin concentration in rodents and humans is the same (Brzezinski et al. 1987, Rönnberg et al. 1990, Bronson \& Heideman 1994). In the present study, $1 \mathrm{pM}$ to $1 \mu \mathrm{M}$ melatonin enhanced sperm hyperactivation (Fig. 2), so it is likely that
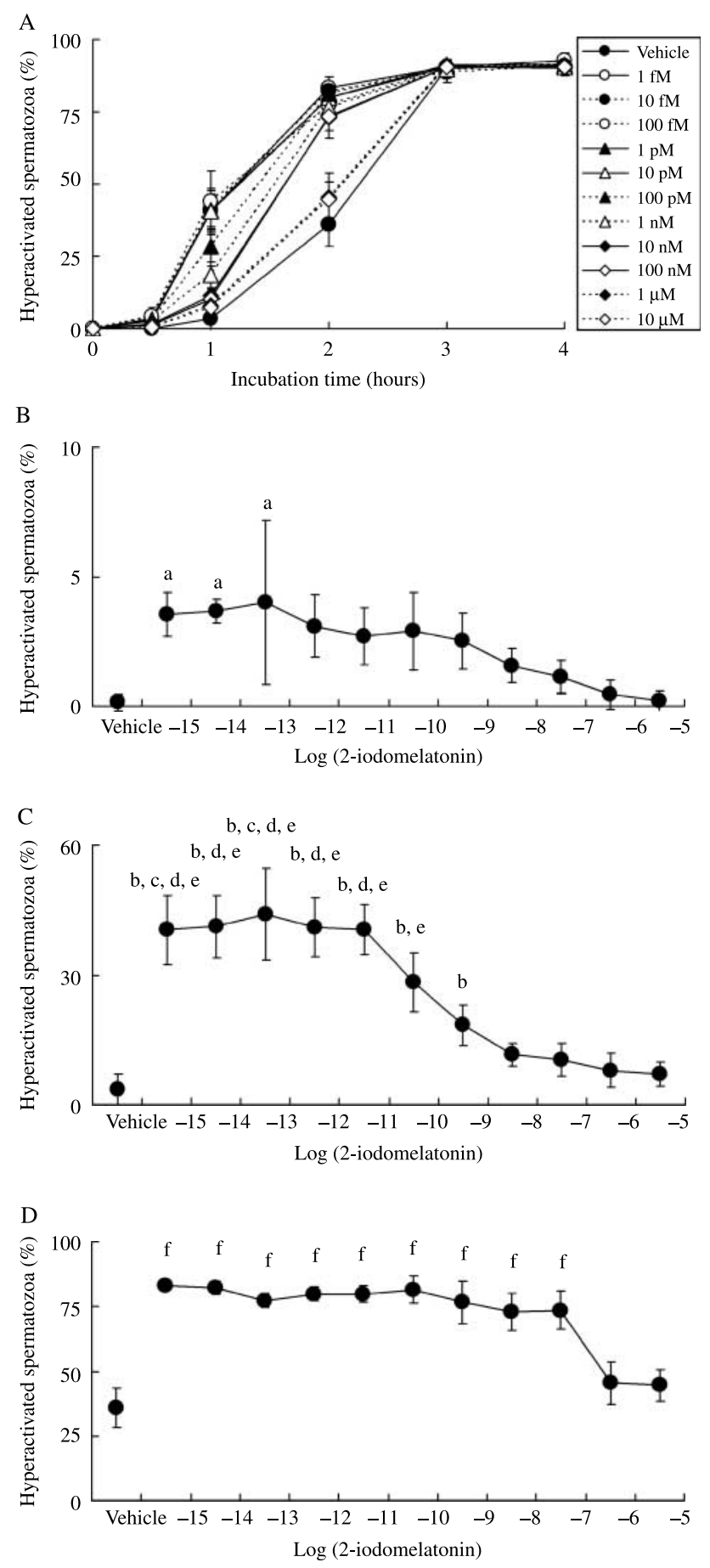

melatonin in both serum and follicular fluid enhances sperm hyperactivation.

Melatonin exerts its effects via receptors, such as MT1 and MT2 (Reppert et al. 1994, 1995), which are seven transmembrane G-protein-coupled receptors (Reppert et al. 1994, 1995). Dubocovich (1988) reported that MT1 was of high-affinity type (picomolar range) and MT2 was of low-affinity type (nanomolar range) in the rodent brain and the chicken retina. Moreover, a melatonin receptor has been found in human spermatozoa and classified as MT2 because it had low affinity in a saturation assay (Van Vuuren et al. 1992). It has been suggested that the melatonin receptor is localized in the sperm midpiece (Pitout et al. 1991, du Toit et al. 1994), although Browning et al. (2000) recently reported that the affinities of human recombinant MT1 and MT2 were essentially similar. Therefore, the type of melatonin receptor in sperm is yet to be determined.

Three melatonin receptor antagonists (luzindole, 4P-PDOT, and DH97; Fig. 3) and three melatonin receptor agonists (8M-PDOT, 6-chloromelatonin, and 2-iodomelatonin; Figs 4-6) were used to investigate the type of sperm melatonin receptor associated with melatonin-enhanced hyperactivation. Luzindole is an MT1 and MT2 competitive antagonist and has a higher affinity for the MT2 receptor (11-fold; Browning et al. 2000). Both 4P-PDOT and DH97 are MT2-specific antagonists. $8 \mathrm{M}$-PDOT is a strong MT2 agonist and a weak MT1 agonist, whereas 6-chloromelatonin and 2 -iodomelatonin are non-specific agonists. Data obtained after the addition of melatonin receptor antagonists and agonists to the medium suggest that stimulation and inhibition of the MT1 receptor regulates melatonin-enhanced hyperactivation of hamster sperm, so it is likely that the receptor is MT1, although there is a

Figure 6 Effects of 2-iodomelatonin, which is a non-specific agonist, on melatonin-enhanced hyperactivation. Percentage of hyperactivated spermatozoa is shown (A) as an overview of effects and after incubation for (B) 0.5, (C) 1, and (D) $2 \mathrm{~h}$ after 2-iodomelatonin was added to the mTALP medium. Data represent mean \pm s.D. (vehicle), $\mathrm{mTALP}+0.1 \%$ ethanol; (1 fM or -15), mTALP+ $1 \mathrm{fM} 2$-iodomelatonin $+0.1 \%$ ethanol; (10 $\mathrm{fM}$ or -14$), \mathrm{mTALP}+10 \mathrm{fM} 2$-iodomelatonin $+0.1 \%$ ethanol; (100 fM or -13), mTALP + 100 fM 2-iodomelatonin $+0.1 \%$ ethanol; (1 pM or -12), mTALP $+1 \mathrm{pM} 2$-iodomelatonin $+0.1 \%$ ethanol; $(10 \mathrm{pM}$ or -11), mTALP + $10 \mathrm{pM} 2$-iodomelatonin $+0.1 \%$ ethanol; $(100 \mathrm{pM}$ or -10), mTALP + 100 pM 2-iodomelatonin + $0.1 \%$ ethanol; (1 nM or - 9), $\mathrm{mTALP}+1 \mathrm{nM} 2$-iodomelatonin $+0.1 \%$ ethanol; $(10 \mathrm{nM}$ or -8$)$, mTALP + $10 \mathrm{nM} 2$-iodomelatonin + 0.1\% ethanol; $(100 \mathrm{nM}$ or -7$)$, mTALP $+100 \mathrm{nM} 2$-iodomelatonin $+0.1 \%$ ethanol; $(1 \mu \mathrm{M}$ or -6$)$, $\mathrm{mTALP}+1 \mu \mathrm{M} 2$-iodomelatonin $+0.1 \%$ ethanol; and $(10 \mu \mathrm{M}$ or -5$)$, $\mathrm{mTALP}+10 \mu \mathrm{M} 2$-iodomelatonin $+0.1 \%$ ethanol. ${ }^{\mathrm{a}}$ Significant difference compared with vehicle or $1 \mu \mathrm{M}$ and $10 \mu \mathrm{M} 2$-iodomelatonin $(P<0.05)$;

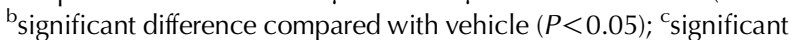
difference compared with $100 \mathrm{pM} 2$-iodomelatonin $(P<0.05)$; ${ }^{\mathrm{d}}$ significant difference compared with $100 \mathrm{nM} 2$-iodomelatonin $(P<0.05)$;

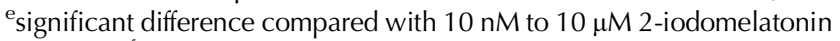
$(P<0.05)$; ${ }^{\mathrm{f}}$ significant difference compared with vehicle or 1 and $10 \mu \mathrm{M}$ 2-iodomelatonin $(P<0.05)$. 

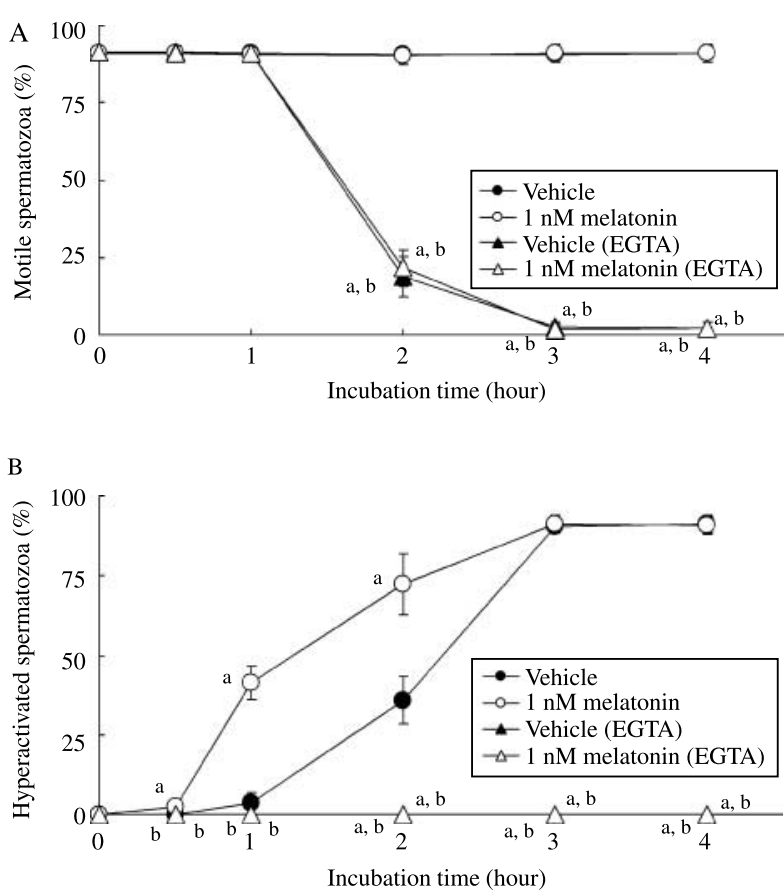

Figure 7 Effects of $\mathrm{Ca}^{2+}$ on melatonin-enhanced hyperactivation. Percentages of (A) motile and (B) hyperactivated spermatozoa are shown, when $\mathrm{Ca}^{2+}$ was removed from the mTALP medium using $1 \mathrm{mM}$ EGTA. Data represent mean \pm s.D. Vehicle $(\bullet), 1 \mathrm{nM}$ melatonin $(O)$, vehicle $(\mathrm{EGTA})(\boldsymbol{\Delta})$, and $1 \mathrm{nM}$ melatonin $(\mathrm{EGTA})(\triangle)$ indicate $\mathrm{mTALP}+$ $0.1 \%$ ethanol, mTALP $+1 \mathrm{nM}$ melatonin $+0.1 \%$ ethanol, mTALP without $\mathrm{Ca}^{2+}+1 \mathrm{mM}$ EGTA $+0.1 \%$ ethanol, and mTALP without $\mathrm{Ca}^{2+}+1 \mathrm{nM}$ melatonin $+1 \mathrm{mM}$ EGTA $+0.1 \%$ ethanol. ${ }^{\mathrm{a}}$ Significant difference compared with vehicle; ${ }^{b}$ significant difference compared with $1 \mathrm{nM}$ melatonin.

need to detect and identify melatonin receptor protein from spermatozoa in future studies.

In order to be hyperactivated, hamster spermatozoa need extracellular $\mathrm{Ca}^{2+}$ and albumin (Noguchi et al. 2008). Because melatonin significantly increased sperm hyperactivation only under these conditions (Figs 7 and $8)$, it is likely that melatonin modulates sperm hyperactivation and controls the timing of it.

Melatonin signals negatively affect cAMP production and $\mathrm{NO}$ production in cells and tissues (Reppert et al. 1994, 1995, Starkey 1996, Vanecek \& Watanabe 1998, Browning et al. 2000, Sáenz et al. 2002, Frungieri et al. 2005). cAMP is very important for sperm function, because sperm flagellar movement and capacitation occur in a cAMP-dependent manner (Morisawa 1994, Visconti \& Kopf 1998, Visconti et al. 1998, Fujinoki et al. $2001 a, 2001 b$ ). It has been suggested that NOS is positively involved in the regulation of capacitation under low concentrations (O'Flaherty et al. 2006, Agarwal et al. 2008, de Lamirande \& O'Flaherty 2008), because high concentrations of $\mathrm{NO}$ negatively affects sperm function (Iwasaki \& Gagnon 1992, Agarwal et al. 2008). Low concentrations of NO stimulate a MAP kinase cascade and tyrosine phosphorylation during

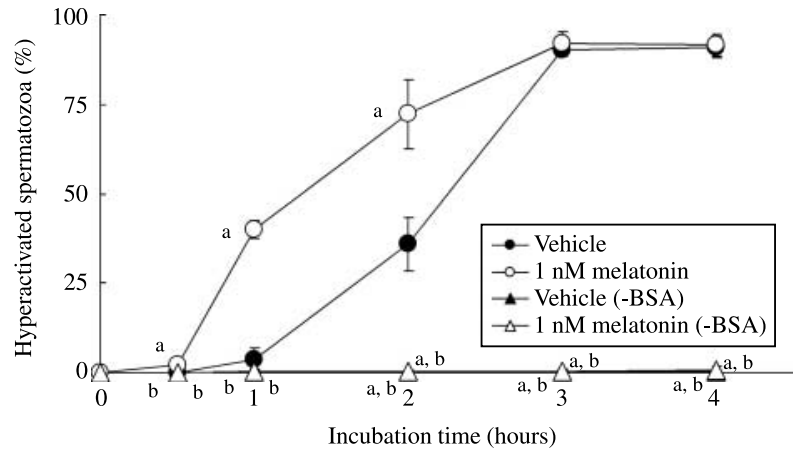

Figure 8 Effect of albumin on melatonin-enhanced hyperactivation. Percentage of hyperactivated spermatozoa is shown when albumin was removed from the mTALP medium. Data represent mean \pm s.D. Vehicle $(\mathbf{O}), 1 \mathrm{nM}$ melatonin $(\bigcirc)$, vehicle $(-\mathrm{BSA})(\boldsymbol{\Delta})$, and $1 \mathrm{nM}$ melatonin $(-B S A)(\triangle)$ indicate $m T A L P+0.1 \%$ ethanol, $m T A L P+1 n M$ melatonin $+0.1 \%$ ethanol, mTALP without albumin $+0.1 \%$ ethanol, and mTALP without albumin $+1 \mathrm{nM}$ melatonin $+0.1 \%$ ethanol.

${ }^{a}$ Significant difference compared with vehicle; ${ }^{b}$ significant difference compared with $1 \mathrm{nM}$ melatonin.

sperm capacitation (de Lamirande \& O'Flaherty 2008). Although it is not well known whether a MAP kinase cascade regulates sperm hyperactivation, it is widely accepted that tyrosine phosphorylation is associated with sperm hyperactivation (Visconti \& Kopf 1998, Visconti et al. 1998, Fujinoki et al. 2001b, 2006). Moreover, it has been suggested that tyrosine phosphorylation is regulated through a MAP kinase cascade (de Lamirande \& O'Flaherty 2008). Therefore, it is likely that a negative effect of melatonin on $\mathrm{NO}$ production, but not on CAMP production, is involved in the modulation of sperm hyperactivation.

\section{Materials and Methods}

\section{Chemicals}

Melatonin was purchased from Sigma Chemical Company. 4P-PDOT, 8M-PDOT, N-acetyl-2-benzyltryptamine (luzindole), $\mathrm{DH} 97$, 6-chloromelatonin ( $\mathrm{N}$-[2-(6-chloro-5-methoxyindol-3yl)ethyl]acetamide), and 2-iodomelatonin ( $N$-[2-(2-iodo-5-methoxyindol-3-yl)ethyl]acetamide) were purchased from Tocris Cookson Ltd (Hung Rd, Bristol, UK). BSA fraction V was purchased from Merck KGaA. Other chemicals of reagent grade were purchased from Wako Pure Chemical Industries (Osaka, Japan).

\section{Preparation of hyperactivated spermatozoa}

Spermatozoa were obtained from the caudal epididymis of sexually mature (12 to 20 weeks old) male golden hamsters (Mesocricetus auratus) that were housed in accordance with the guidelines of the Dokkyo Medical University and the Laboratory Animal Research Center in Dokkyo Medical University for the care and use of laboratory animals.

Hyperactivated spermatozoa were prepared according to the method described by Si \& Okuno (1999) using the mTALP 
(modified Tyrode's albumin lactate pyruvate) medium. An aliquot of caudal epididymal spermatozoa was placed at the bottom of a test tube and several milliliters of medium were carefully added before incubation for $5 \mathrm{~min}$ to allow spermatozoa to swim up. The supernatant containing motile spermatozoa was collected, placed on a culture plate $(35 \mathrm{~mm}$ dish), and incubated for $4 \mathrm{~h}$ at $37{ }^{\circ} \mathrm{C}$ under $5 \% \mathrm{CO}_{2}$ in air to accomplish hyperactivation. Melatonin, its agonists and melatonin receptor antagonist dissolved in ethanol (EtOH) were added to the medium after placing motile spermatozoa on the culture plate. In all experiments, the final concentration of $\mathrm{EtOH}$ was $0.1 \%$.

\section{Measurement of the motility and hyperactivation of spermatozoa}

Motility and hyperactivation measurements were performed according to the method of Fujinoki et al. (2006) with some modifications. Spermatozoa suspended in the mTALP medium were diluted tenfold and placed on a culture plate. Motility and hyperactivation were recorded on S-VHS via a CCD camera (Progressive 3CCD; Sony Corp., Tokyo, Japan) attached to a microscope (IX70; Olympus Corp., Tokyo, Japan) with phasecontrast illumination and a small $\mathrm{CO}_{2}$ incubator (MI-IBC; Olympus). Each observation was performed at $37^{\circ} \mathrm{C}$, recorded for $2 \mathrm{~min}$, and analyzed by manually counting the numbers of total spermatozoa, motile spermatozoa, and hyperactivated spermatozoa in 20 different fields. Motile spermatozoa that exhibited asymmetric and whiplash flagellar movement (Fujinoki et al. 2001a) and a circular and/or octagonal swimming locus were defined as hyperactivated spermatozoa. Motile (\%) and hyperactivated spermatozoa (\%) were respectively defined as the number of motile spermatozoa/number of total spermatozoa $\times 100$, and the number of hyperactivated spermatozoa/number of total spermatozoa $\times 100$. Experiments were performed four times using four hamsters. Statistical analysis was carried out using the Student's $t$-test or the post hoc test of ANOVA. $P<0.05$ was considered significant.

\section{Declaration of interest}

The author declares that there is no conflict of interest that could be perceived as prejudicing the impartiality of the research reported.

\section{Funding}

This work was supported by a Grant-in-Aid for Young Scientists (B) from the Ministry of Education, Culture, Sports, Science and Technology of Japan (no. 18791135).

\section{References}

Agarwal A, Makker K \& Sharma R 2008 Clinical relevance of oxidative stress in male factor infertility: an update. American Journal of Reproductive Immunology 59 2-11.

Bornman MS, Oosthuizen JMC, Barnard HC, Schulenburg GW, Boomker D \& Reif S 1989 Melatonin and sperm motility. Andrologia 21 483-485.
Bronson FH \& Heideman PD 1994 Seasonal regulation of reproduction in mammals. In The Physiology of Reproduction vol 2, edn 2, pp 541-582. Eds E Knobil and JD Neill. New York: Raven Press.

Browning C, Beresford I, Fraser N \& Giles H 2000 Pharmacological characterization of human recombinant melatonin $\mathrm{mt}_{1}$ and $\mathrm{MT}_{2}$ receptors. British Journal of Pharmacology 129 877-886.

Brzezinski A, Seibel MM, Lynch HJ, Deng MH \& Wurtman RJ 1987 Melatonin in human preovulatory follicular fluid. Journal of Clinical Endocrinology and Metabolism 64 865-867.

Dubocovich ML 1988 Pharmacology and function of melatonin receptors. FASEB Journal 2 2765-2773.

Frungieri MB, Mayerhofer A, Zitta K, Pignataro OP, Calandra RS \& Gonzalez-Calvar SI 2005 Direct effect of melatonin on Syrian hamster testes: melatonin subtype 1a receptors, inhibition of androgen production, and interaction with the local corticotrophin-releasing hormone system. Endocrinology 146 1541-1552.

Fujinoki M, Ohtake H \& Okuno M 2001a Serine phosphorylation of flagellar proteins associated with the motility activation of hamster spermatozoa. Biomedical Research 22 45-58.

Fujinoki M, Ohtake H \& Okuno M 2001b Tyrosine phosphorylation and dephosphorylation associated with motility of hamster spermatozoa. Biomedical Research 22 147-155.

Fujinoki M, Suzuki T, Takayama T, Shibahara H \& Ohtake H 2006 Profiling of proteins phosphorylated or dephosphorylated during hyperactivation on hamster spermatozoa. Reproductive Medicine and Biology 5 123-135.

Fukami K, Nakano K, Inoue T, Kataoka Y, Kurokawa M, Fissore RA, Nakamura K, Katsuki M, Mikoshiba K, Yoshida N et al. 2001 Requirement of phospholipase $\mathrm{C} \delta 4$ for the zona pellucida-induced acrosome reaction. Science 292 920-923.

Furuya S, Endo Y, Oba M, Matsui Y, Suzuki S \& Nozawa S 1994 Effect of epidermal growth factor on mouse sperm acrosome reaction induced by zona pellucida. American Journal of Reproductive Immunology31 116-122.

Gwayi N \& Bernard RTF 2002 The effects of melatonin on sperm motility in vitro in Wistar rats. Andrologia 34 391-396.

Ho HC \& Suarez SS 2001 An inositol 1,4,5-trisphoshate receptor-gated intracellular $\mathrm{Ca}^{2+}$ store is involved in regulating sperm hyperactivated motility. Biology of Reproduction 65 1606-1616.

Ho HC, Granish KA \& Suarez SS 2002 Hyperactivated motility of bull sperm is triggered at the axoneme by $\mathrm{Ca}^{2+}$ and not cAMP. Developmental Biology 250 208-217.

Iwasaki A \& Gagnon C 1992 Formation of reactive oxygen species in spermatozoa of infertile patients. Fertility and Sterility $\mathbf{5 7} 409-416$.

Kokolis N, Theodosiadou E, Tsantarliotou M, Rekkas C, Goulas P \& Smokovitis A 2000 The effect of melatonin implants on blood testosterone and acrosin activity in spermatozoa of the ram. Andrologia 32 107-114.

Kvetnoy IM 1999 Extrapineal melatonin: location and role within diffuse neuroendocrine system. Histochemical Journal 31 1-12.

de Lamirande E \& O'Flaherty C 2008 Sperm activation: role of reactive oxygen species and kinases. Biochimica et Biophysica Acta 1784 106-115.

Langlais J \& Roberts KD 1985 A molecular membrane model of sperm capacitation and the acrosome reaction of mammalian spermatozoa. Gamete Research 13 183-224.

Meizel S \& Turner KO 1983 Serotonin or its agonist 5-methoxytryptamine can stimulate hamster sperm acrosome reactions in a more direct manner than catecholamines. Journal of Experimental Zoology 226 171-174.

Morisawa M 1994 Cell signaling mechanisms for sperm motility. Zoological Science 11 647-662.

Noguchi T, Fujinoki M, Kitazawa M \& Inaba N 2008 Regulations of hyperactivation of hamster spermatozoa by progesterone. Reproductive Medicine and Biology 7 63-74.

O'Flaherty C, de Lamirande E \& Gagnon C 2006 Positive role of reactive oxygen species in mammalian sperm capacitation: triggering and modulation of phosphorylation events. Free Radical Biology \& Medicine 41 528-540.

Okamura N, Tajima Y, Soejima A, Masuda H \& Sugita Y 1985 Sodium bicarbonate in seminal plasma stimulates the motility of mammalian spermatozoa through the direct activation of adenylate cyclase. Journal of Biological Chemistry $2609699-9705$.

Osman RA, Andria ML, Jones AD \& Meizel S 1989 Steroid induced exocytosis: the human sperm acrosome reaction. Biochemical and Biophysical Research Communications 160 828-833. 
Pitout NJ, Van Vuuren RJJ, Van Aswegen CH \& Theron JJ 1991 Melatonin and sperm motility. South African Medical Journal 79683.

Reppert SM, Weaver DR \& Ebisawa T 1994 Cloning and characterization of a mammalian melatonin receptor that mediates reproductive and circadian responses. Neuron 13 1177-1185.

Reppert SM, Godson C, Mahle CD, Weaver DR, Slaugenhaupt SA \& Gusella JF 1995 Molecular characterization of a second melatonin receptor expressed in human retina and brain: the Mel1b melatonin receptor. PNAS 92 8734-8738.

Rönnberg L, Kauppila A, Leppäluoto J, Martikanen H \& Vakkuri O 1990 Circadian and seasonal variation in human preovulatory follicular fluid melatonin concentration. Journal of Clinical Endocrinology and Metabolism 71 493-496.

Sáenz DA, Turjanski AG, Sacca GB, Marti M, Doctorovich F, Sarmiento MIK, Estrin DA \& Rosenstein RE 2002 Physiological concentrations of melatonin inhibit the nitridergic pathway in the Syrian hamster retina. Journal of Pineal Research 33 31-36.

Si Y \& Okuno M 1999 Role of tyrosine phosphorylation of flagellar proteins in hamster sperm hyperactivation. Biology of Reproduction 61 240-246.

Starkey SJ 1996 Melatonin and 5-hydroxytryptamine phase-advance the rat circadian clock by activation of nitric oxide synthesis. Neuroscience Letters 211 199-202.

Suarez SS \& Ho HC 2003 Hyperactivated motility in sperm. Reproduction in Domestic Animals 38 119-124.

du Toit D, Bornman MS, Van Aswegen CH \& Du Plessis DJ 1994 Sialic acid concentration and sperm motility. Archives of Andrology 32 21-23.

Turek FW \& Van Cauter E 1994 Rhythms in reproduction. In The Physiology of Reproduction vol 2, edn 2, pp 487-540. Eds E Knobil and JD Neill. New York: Raven Press.
Vanecek J \& Watanabe K 1998 Melatonin inhibits the increase of cyclic AMP in rat suprachiasmatic neurons induced by vasoactive intestinal peptide. Neuroscience Letters 252 21-24.

Visconti PE \& Kopf GS 1998 Regulation of protein phosphorylation during sperm capacitation. Biology of Reproduction 59 1-6.

Visconti PE, Galantino-Homer H, Ning X, Fornes MW, Moore GD, Bailey JL \& Kopf GS 1998 The molecular basis of capacitation. Journal of Andrology 19 242-248.

Van Vuuren RJJ, Du Plessis DJ \& Theron IJ 1988 Melatonin in human semen. South African Medical Journal 73 374-375.

Van Vuuren RJJ, Pitout MJ, Van Aswegen CH \& Theron JJ 1992 Putative melatonin receptor in human spermatozoa. Clinical Biochemistry 25 125-127.

Weaver DR \& Reppert SM 1996 The Mel1a melatonin receptor gene is expressed in human suprachiasmatic nuclei. Neuroreport 8 109-112.

Yanagimachi R 1994 Mammalian fertilization. In The Physiology of Reproduction vol 2, edn 2, pp 189-317. Eds E Knobil and JD Neill. New York: Raven Press.

Yudin Al, Gottlieb W \& Meizel S 1988 Ultrastructural studies of the early events of the human sperm acrosome reaction as initiated by human follicular fluid. Gamete Research 20 11-24.

Received 13 May 2008

First decision 11 June 2008

Revised manuscript received 28 July 2008

Accepted 20 August 2008 